\title{
ACTH and the phosphorylation of proteins and phosphatidylinositides
}

Citation for published version (APA):

Jolles, J., Zwiers, H., Schotman, P., \& Gispen, W. H. (1980). ACTH and the phosphorylation of proteins and phosphatidylinositides. In Synaptic Constituents in Health and Disease: Proceedings of the Third Meeting of the European Society for Neurochemistry, Bled, August 31st to September (pp. 269-279). Mladinska Knjiga.

Document status and date:

Published: 01/01/1980

Document Version:

Publisher's PDF, also known as Version of record

\section{Please check the document version of this publication:}

- A submitted manuscript is the version of the article upon submission and before peer-review. There can be important differences between the submitted version and the official published version of record.

People interested in the research are advised to contact the author for the final version of the publication, or visit the DOI to the publisher's website.

- The final author version and the galley proof are versions of the publication after peer review.

- The final published version features the final layout of the paper including the volume, issue and page numbers.

Link to publication

\footnotetext{
General rights rights.

- You may freely distribute the URL identifying the publication in the public portal. please follow below link for the End User Agreement:

www.umlib.nl/taverne-license

Take down policy

If you believe that this document breaches copyright please contact us at:

repository@maastrichtuniversity.nl

providing details and we will investigate your claim.
}

Copyright and moral rights for the publications made accessible in the public portal are retained by the authors and/or other copyright owners and it is a condition of accessing publications that users recognise and abide by the legal requirements associated with these

- Users may download and print one copy of any publication from the public portal for the purpose of private study or research.

- You may not further distribute the material or use it for any profit-making activity or commercial gain

If the publication is distributed under the terms of Article $25 \mathrm{fa}$ of the Dutch Copyright Act, indicated by the "Taverne" license above, 
ACTH AND THE PHOSPHORYLATION OF PROTEINS AND PHOSPHATIDYLINOSITIDES

J. Jolles, H. Zwiers, P. Schotman and W. H. Gispen

Division of Molecular Neurobiology, Institute of Molecular Biology, University of Utrecht, The Netherlands

Phosphorylation of membrane components is thought to be an important process in membrane function. Phosphorylated proteins are implicated in the regulation of neuronal membrane permeability and synaptic transmission (1) while the same is suggested for a special class of phospholipids, the polyphosphoinositides (2). The breakdown of phosphatidylinositol (PI) to 1,2-diacy1-g1ycerol and its rapid resynthesis via phosphatidic acid (PA) is a common phenomenon upon agonist-receptor interaction. The "PI-response" occurs in a variety of tissues and is thought to regulate the $\mathrm{Ca}^{2+}$ influx into the cell while the phosphorylation of PI to Phosphatidylinosito1-4-Phosphate (DPI) and Phosphatidylinosito1-4,5-diphosphate (TPI) may regulate $\mathrm{Ca}^{2+}$ binding to the inside of the membrane (2).

Brain membrane protein phosphorylation was studied in the presence of behaviorally active peptides derived from adrenocorticotrophic hormone: $\mathrm{ACTH}_{1-24}$ exerted a dose- and structure-dependent inhibitory effect on the in vitro phosphorylation of a specific protein in synaptosomal plasma membranes. The phosphorylation of this protein (B-50, MW 48,000; IEP 4,5) was shown to be $\mathrm{Ca}^{2+}$-dependent $(3,4)$. Fur thermore, we found that $\mathrm{ACTH}_{1-24}$ affected polyPI metabo1 ism in crude synaptosomal fractions from rat brain (5). The question then arose whether the phosphorylation of membrane proteins and membrane lipids is interrelated as both processes seemed to be influenced in the same membrane by ACTH. The ACTH-sensitive protein kinase/B-50 protein complex was recently isolated in soluble form from rat brain synaptosomal plasma membrane: the Triton-solubilized membrane proteins were separated by DEAE cellulose column chromatography followed by ammonium sulphate precipitation (ASP). The ASP 55-80\% fraction contains B-50 and its kinase, and a limited number of other proteins. B-50 is the only phosphoprotein, and its phosphorylation is still sensitive to ACTH $1-24$. Interestingly, addition of exogenous DPI to the DEAE- and ASP $_{55-80 \%}$ fractions in the presence of radioactive ATP produced radioactively labelled TPI and Phosphatidic Acid (PA). An inverse relationship was found between $B-50$ phosphorylation and $32 \mathrm{TPI}-$ production, $i . e$. more TPI was formed when $B-50$ was in a relatively nonphosphorylated state (Table I). Also in studies on the effect of ACTH we found that inhibited B-50 phosphorylation is correlated with more 32 TPI production (Table I). The results obtained so far are suggestive of a functional relation between $B-50$ protein phosphorylation and polyPI metabolism. We suggest that the state of 
TABLE I

THE RELATION BETWEEN B-50 PROTEIN PHOSPHORYLATION AND TPI FORMA'ION

\begin{tabular}{llcc}
\hline Treatment & & $\begin{array}{c}\text { Incorporation, } \\
\text { B-50 of contro1 } \\
\text { TPI }\end{array}$ \\
\hline A. ACTH $1-24(10 \mu \mathrm{M})$ & $52 \%$ & $135 \%$ \\
$\quad$ ACTH $_{1-24}(100 \mu \mathrm{M})$ & $31 \%$ & $249 \%$ \\
B. B-50 prephosphorylation &, $10 \mathrm{~min}$ & - & $83 \%$ \\
&, $20 \mathrm{~min}$ & - & $68 \%$ \\
&, $30 \mathrm{~min}$ & - & $54 \%$ \\
&, $40 \mathrm{~min}$ & - & $31 \%$ \\
\hline
\end{tabular}

(A) ASP 55-80\% fraction was incubated for $15 \mathrm{~min}$ in the presence of DPI and $\gamma^{-32}$ P|ATP (for details concerning the phosphorylation assay, see ref.4). ACTH was added $15 \mathrm{sec}$ before the addition of DPI and ATP. The labe1 incorporated into TPI and B-50 was measured.

(B) ASP $_{55-80 \%}$ fraction was incubated for various time periods $(0$, $10,20,30,40 \mathrm{~min})$ in the presence of $\left|\gamma^{-32} \mathrm{P}\right| \mathrm{ATP}$. B-50 was the only labelled phosphoprotein and incorporation increased with time up to $40 \mathrm{~min}$. DPI was added after this B-50 prephosphorylation period and incubation continued for another $5 \mathrm{~min}$.

phosphorylation of $\mathrm{B}-50$ may regulate the DPI kinase activity. In view of the suggested role of both protein phosphorylation and polyPI metabolism in neuronal membranes $(1,2)$, the presently reported data'may imply that phosphorylation of a quantitatively minor membrane protein $(\mathrm{B}-50)$ brings about profound changes in membrane characteristics by changing the amount of polyphosphoinositides in that membrane.

1. Greengard, P. (1978): Science 199, 146-152.

2. Michel1, R. H. (1975): Biochim. Biophys. Acta 415, 81-148.

3. Zwiers, H., Wiegant, V. M., Schotman, P., Gispen, W.H. (1978): $3,455-463$.

4. Zwiers, H., Tonnaer, J., Wiegant, V.M., Schotman, P., Gispen, W.H. (1979): J. Neurochem. 33, 247-256.

Zwiers, H., Schotman, P., Gispen, W.H., J. Neurochem, in press.

5. Jolles, J., Wirtz, K.W.A., Schotman, P., Gispen, W.H.. (1979): FEBS Lett. $105,110-114$. 
PEPTIDE RECEPTORS OF NEURAL CELLS IN VITRO: CAMP

D. Van Calker, F. Löffler and B. Hamprecht

Physiologisch-Chemisches Institut der Universität, Koellikerstr. 2, 8700 würzburg, F.R.G.

Due to the complexity of nervous tissue the elucidation of molecular mechanisms underlying physiological processes is difficult. Dispersed neural cells in culture are systems simple enough to allow such studies. Two such systems are currently applied: 1) Cell lines derived from tumors of the nervous system, e.g., neuroblastoma $\mathrm{x}$ glioma hybrid cells. 2) Primary cultures derived from normal nervous tissue. They have proven useful in the elucidation of the mode of action of certain (neuro)hormones that regulate the cellular level of cyclic AMP. These (neuro)hormones can be divided into two classes: Those that stimulate and those that inhibit the formation of cyclic AMP. In the hybrid cells, the gastrointestinal peptides secretin and glucagon stimulate whereas opioid peptides and somatostatin inhibit. These principles established in the hybrid cell system hold also for primary cultures from perinatal mouse brain that consist mainly of cells that can differentiate into astrocyte-like cells. In these cultures the generation of cyclic AMP is stimulated by the peptides secretin and VIP and inhibited by somatostatin. These and other results point to a regulatory influence of peptide hormones on glial cells. Though secretin-like material has not yet been detected in brain, out studies suggest that it may be occurring there and serve an important function. 

DOPAMINERGIC INTERACTIONS OF THE POTENTIAL
NEUROLEPTIC PEPTIDE $\beta-$ LPH $_{62-77}$ (des-Tyr ${ }^{1}-\gamma$-endorphin;
DT $\gamma$ )

V.J. Nickolson

Organon International B.V., Kloosterstraat 6, The Netherlands

The dopaminergic interactions of DTYE were assessed using the dopamine (DA) agonist apomorphine (APO).

1. Climbing induced in mice by high $\left(0.5-1.0 \mathrm{mg}^{-\mathrm{kg}^{-1}}\right.$, s.c.)

doses of APO was studied. Unlike haloperidol (Hal), DTYE did not inhibit climbing in doses up to $2 \mathrm{mg} \cdot \mathrm{kg}^{-1}$ (s.c.).

2. Yawning and decrease of activity induced in rats by low $(0.02-$ $0.2 \mathrm{mg} . \mathrm{kg}^{-1}$ s.c.) doses of APO were studied. DTYE potentiated whereas $\mathrm{Hal}$ inhibited APO-induced yawning and decrease of activity.

3. The effects of APO on HVA levels in rat $n$. accumbens and striatum were studied. DTYE potentiated the HVA decrease induced by low doses of APO.

4. The effect of DTYE and $\mathrm{Hal}$ on $\mathrm{K}^{+}$-induced release of DA from brain slices in vitro was studied. DTYE depressed, whereas $\mathrm{Hal}$ increased $\mathrm{K}^{+}$-induced DA release.

5. The effect of APO on rat serum prolactin (PRL) was studied. DTYE did not affect the strong decrease in PRL levels induced by low doses of APO.

Tentative conclusions: DTYE does not block the postsynaptic DAreceptor (1) but sensitizes a presynaptic receptor, thereby reinforcing probably the local feed back system at the DA nerve ending $(2,3,4)$. DT $\gamma E$ does not affect the DA-ergic regulation of PRL release (5). The pharmacological profile of DTYE thus strongly differs from that of $\mathrm{Hal}$, but they may share the property to decrease DA-ergic activity, DTYE by reinforcing a local feedback system and $\mathrm{Hal}$ by blocking the postsynaptic receptor. 
SATIETIN: A HIGHLY POTENT ANOREXOGENIC SUBSTANCE IN MAMMALIAN BLOOD.

J. Kno11, Bertha Kno11 and H. Ka1dsz

Department of Pharmacology, Semmelweis University of Medicine, Budapest, Hungary.

A substance named satietin, capable of reducing food intake drastica11y in rats deprived of food for $96 \mathrm{hr}$, was discovered in human serum ( $\mathrm{J}$. Knoll, physiol, and Behavior, 23, 497-502, 1979), and detected in the blood cf different species. The substance was extracted by gelchromatography of the ultrafiltrate of different sera (filtered through Amicon UM-10 membrane) on Sephadex G-15 gel column and purified by rechromatography of the biological active fractions on a Bio-Gel p-30 column. Highly purified satietin samples extracted from human serum showing one band only in polyacrylamide gelelectrophoresis, containing in average $60,6 \%$ amino acids and $13,5 \%$ carbohylrates, were used for biological experiments. The anorexogenic effect of these highly purified glycoprotein samples were tested on rats deprived of food for. 96 hours. Untreated fasted rats ate $8,40+0,35$ and $24,04+0,76 \mathrm{~g}$ of food (chow pellets) within 1 and 24 hours, respectively. The intracerebroventricular injection of 10-100 ug satietin five hour's bebefore the test meal decreased food consumption drastically and in a dose-dependent manner. E.g. the injection of 100 ug of highly purified satietin decreased the consumption of chow pellets to $1,1+0.51$ and $7,75+1,27 \mathrm{~g}$ within 1 and 24 hours, respectively. Water intake remained unchanged on the satietin treated rats. The hypothesis is forwarded that satietin might play the role of a rate limiting satiety signal in the negative feed back of food intake. The "satietin-1ike" long lasting inhibition of food intake seems to be unique. Endogenous peptides, known to possess an anorectic effect, are either inactive (cholecystokinin) or very slightly inhibitory (pGlu-His-GlyOH) on rats deprived of food for 96 hours. The anorectic effect of amphetamine and structuraliy related releasers of the catecholamines is of short duration and their effect can be antagonized by pretreatment with $\propto$-methyparatyrosine, which leaves the effect of satietin unchanged. The anorectic effect of LSD, fenfluramine and other halogenated phenylalkylamines, like p-bromomethamphetamine $(\mathrm{V}-111)$ which seems to be linked with serotonergic transmission in the brain, is also markedly different from the effect of satietin. 
DEMONSTRATION OF PEPTIDE-LIKE LIGANDS FOR BENZODIAZEPINE RECEPTOR。

A. Kenessey, T. Láng and L. Gráf

Institute for Drug Research, P.O.Box 82., H-1325

Budapest, Hungary.

High-affinity binding sites for benzodiazepines have been demonstrated suggesting that endogenous 1 igand/s/ may also exist in the brain. Recently, inosine and hypoxanthine have been isolated from the brain and identified as competitive inhibitors of benzodiazepine binding /for review see Marangos et al./. The affinity of these putative ligands for the receptor, however, has been reported to be very low as compared to that of benzodiazepines.

In our attempts to identify further "benzodiazepinelike" factor/s/, some aqueous extracts of bovine brain were tested for ${ }^{3} \mathrm{H}$-diazepam displacing activity. Our results showed that the majority of active substances in the extracts was non-dialyzable. In response to pronase digestion about 608 of the "benzodiazepinelike" activity of the dialyzed extracts was lost indicating that substances of peptide nature might also contribute to receptor binding. Chromatography of the brain extracts on a Sephadex G-75 column revealed that they were composed of at least four active fractions with molecular weights of 60000 to 5000 . Further purification and chemical and biological characterization of these substances are being carried out.

Marangos, P.J., Paul, S.M. and Goodwin, F.K. /1979/: Life Sci. 25, 1093-1102. 
EFFECT OF CAPSAICIN ON THE CONTENT OF SOMATOSTATIN, SUBSTANC P AND NEUROTENSIN IN THE CENTRAL AND PERIPHERAL NERVOUS SYSTEM OF THE RAT

R. Gamse, S.E. Leeman, P. Holzer ${ }^{*}$ and F. Lembeck ${ }^{*}$

Department of Physiology, Harvard Medical School, Boston and Department of Pharmacology, Univ. Graz, Austria

Local application of capsaicin (CAP) stimulates pain receptors and hypothalamic thermoreceptors. Repetitive local or systemic administration leads to desensitization. Systemic CAP-pretreatment of newborn but not of adult rats causes degeneration of small diameter primary sensory neurons. CAP acutely releases and subsequently depletes substance P (SP) from primary sensory neurons but not from hypothalamus. We investigated whether CAP selectively depletes $\mathrm{SP}$ or also somatostatin (SOM) or neurotensin (NT) .

Newborn rats were injected with CAP $(50 \mathrm{mg} / \mathrm{kg}, \mathrm{s.c.})$ and peptide levels determined 6 and 17-20 weeks later. At both time points a $61-89 \%$ ( $\mathrm{P}<0.001$ ) depletion of SOM and SP was found in saphenous nerve (S), dorsal root ganglia (DRG), and dorsal roots (DR). SOM $(-23 \%)$ and SP $(-63 \%)$ were also decreased in the dorsal half of the spinal cord (dSC) but not in the ventral half (vSC). While both peptides were depleted by $70 \%$ in the trigeminal ganglion (TG), a decrease of SP only was found in the medulla oblongata (MO, $-50 \%$ ). SOM and SP were unchanged in preoptic area (PO) and hypothalamus (H).

In adult rats examined 1 week after CAP-pretreatment (125 $\mathrm{mg} / \mathrm{kg}$, s.c.), a small depletion of SOM was found only in $S(-23 \%)$ and dSC $(-16 \%)$. SP, however, was depleted in S $(-58 \%)$, DRG $(-39 \%)$ DR $(-62 \%)$, dSC $(-41 \%)$, TG $(-42 \%)$, and MO $(-37 \%)$. The same dose of CAP given $1 . p$. was more effective in depleting SOM and SP, causing a decrease of SOM also in DRG and DR. 19 weeks after s.c. CAP pretreatment SOM levels were not different from controls; SP was still depleted in MO, but partly restored in DR and $\mathrm{dSC}$, and fully in $S$ and DRG.

Injection of $250 \mathrm{\mu g}$ CAP into the lateral ventricle of adult rats caused no change of SOM and SP in PO, H, and TG but depleted SP in $\mathrm{MO}$ by $25 \%$.

NT remained unchanged in $\mathrm{PO}, \mathrm{H}, \mathrm{MO}, \mathrm{dSC}$, and $\mathrm{VSC}$ in a1l experiments. It was undetectable in peripheral nerves.

Conclusions: CAP depletes both SP and SOM from primary sensory neurons. Its effect is apparently irreversible after pretreatment of newborn rats but reversible in rats injected as adults. 
NALOXONE-STIMULATED HIGH AFFINITY UPTAKE OF LEU-ENKEPHALIN BY GLIA-ENRICHED FRACTION OF THE RABBIT BRAIN.

\section{J. Wideman, J. Wróblewski and J. Lazarewicz}

Medical Research Centre of the Polish Academy of Sciences, 00-784 Warsaw, 3 Dworkowa Str., Poland.

In the present study experimental difficulties overcoming of which is essential for obtaining reliable results on uptake of enkephalins by cell fractions of the brain are described.

Since most of the labeled peptides from commercial sources are contaminated ${ }^{1}$ chromatography on Sephadex LH $-20^{2}$ was applied for purifying tritiated Leuenk we used, since the sample was contaminated with extra radioactive material/over $50 \%$ / which was accumulated by glia. While using original sample we failed to determine $\mathrm{K}$ for the uptake. To separate extra- and intra-glia pools of radioactivity chromatography on Sephadex G-15 was used. After washing out the extra-glia pool the retained glia cells were ruptured with water to obtain the intra-glia pool. Upon chromatography on Sephadex LH-20 most of the radioactivity in both pools was found to be tritiated tyrosine/Tyr/ released from Leu-enk. To find whether intra-glia labeled Tyr is released from already accumulated Leu-enk or comes from Tyr released extracellular1y from Leu-enk and then accumulated an exoess of unlabeled Tyr in incubation medium was used to decrease accumulation of labeled Tyr of latter origin.

Conclusions of the present work are as follows:

Leu-enk is accumulated by glia-enriched fraction by high and low affinity uptake. High affinity uptake is stimulated by opiate antagonist, naloxon.

${ }^{1}$ Wideman, J., Stein, S. /1978/: Proc. Second ESN Meeting, Verlag Chemie, Weinhetm, New York, p. 457. 2 Wideman, J., Stein, S. /1978/: as above, p. 458 . 
AUTORADIOGRAPHIC DEMONSTRATION OF PEPTIDE BIOSYNTHESIS IN MOUSE BRAIN HOMOGENATES.

$\underline{P}$. Lähdesmäki and $\underline{\mathrm{K}}$. Airaksinen

Department of Biochemistry, University of Oulu, Box 191, 90101 Oulu 10, Finland.

Mammalian brain contains a great number of low-molecular weight peptides containing 4-6 amino acid residues and having N-acetylaspartate (N-AC-Asp) as their important constituent. ${ }^{1-2}$ we used here a combined autoradiographic-thin layer-chromatographic technique to show the incorporation of labelled amino acids into some N-Ac-Asp peptides in mouse brain homogenates. The brain homogenates were incubated in the presence of $\mathrm{N}$-AC-Asp and $\left[35_{\mathrm{S}}\right]$ taurine, $\left[{ }^{14} \mathrm{C}\right]$ glutamate, $\left[{ }^{14} \mathrm{C}\right]$ aspartate or $\left[{ }^{14} \mathrm{C}\right]$ GABA. Two-dimensional chromatograms were developed on TLC plates and the radioactive products formed from the labelled amino acids detected by covering the plates with a kodak $\mathrm{X}$-Omat film for one week. - A great number of unknown hydrolysable products (in the best case almost 20 ) was obtained. The labelled products formed were in general ninhydrinnegative, a property characteristic of N-Ac-Asp peptides. Some non-hydrolysable products, also were obtained, these being apparently metabolic derivatives of the amino acids.

This study was supported by the Science Research Council of Finland.

1. Reichelt, K.L. and Kvamme, E. (1973): J. Neurochem. 21, 849-859.

2. Lähdesmäki, P., Vartiainen, M. and Halonen, P. (1980): Acta Chem. Scand. (in press). 
PROTEIN SYNTHESIS IN A CELL-EREE SYSTEM FROM RAT BRAIN TISSUE SENSITIVE TO ACTH AND ENDORPHIN-LIKE PEPTIDES

Peter Schotman and willem Hendrik Gispen

Division of Molecular Neurobiology, Institute of Molecular Biology, University of Utrecht, The Netherlands.

Protein synthesis was measured using, a cell-free system obtained from subcortical rat brain tissue. The concentrations of $\mathrm{Mg}^{2+}$ and $\mathrm{K}^{+}$and the amount of tissue, both during the preparation and the final assay, were critical to the incorporation of amino acids as expressed per mg protein. Even under optimal conditions reinitiation was still limited.

Behaviorally active fragments of ACTH modulated the activity of the system both after prior administration in vivo and after addition to the incubation medium, in vitro. In vitro, a biphasic effect was shown, i.e. at low concentrations $\left(10^{-7} .10^{-10} \mathrm{M}\right)$ of ACTH a stimulation was found, a high concentration $\left(10^{-4} \mathrm{M}\right)$ was inhibitory. Structure-activity studies revealed that the stimulatory effect was confined to the $\mathrm{N}$-terminus of the peptide, whereas the C-terminal sequence was responsible for the inhibition. When in the peptide sequence 4-10, the 7-L-phenylalanine was replaced by its D-isomer, the peptide showed a concentration dependency quite opposite to that of the L-peptide. Opposite effects of these peptides have been described on avoidance behavior before.

The present data on the modulation of protein synthesis in a cellfree system by ACTH-like peptides are in agreement with those described on leucine-incorporation into brain stem proteins in vivo, before. This might imply a direct intracellular effect of ACTH on brain protein synthesis.

Endorphins were also active in modulation of cell-free protein synthesis. In this case, structure-activity studies revealed two active sites within the $\alpha$-endorphin sequence, being $\beta-L P H ~(62-65)$ and $\beta-L P H(70-76)$. The significance for the biological effects of these peptides will be discussed.

De Wied, D. (1969) Frontiers in Neuroendocrinology, 653-666

Schotman, P. et al. (1972) Brain Res. 46, 349-362

Schotman, P. et al. (1980) J. Neurochem. 34 (6), in press 
ON IHE BRAIN PHOSFHOPEP'LIDES AEIUALING IN ALINO ALIV OXIDAIIVE DEAMINATION PROCESSES.

I.A. Edilashvili, D.G. Kacharava and T.G. Garishvili

I. Beritashvili Institute of Physiology, Georgian SSR Academy of Sciences, 380060 Tbilisi, USSR.

Ammonia liberating in brain amino acid oxidative deamination reactions is bound in compounds extractable by chloroform-methanol mixture from TCA - precipitate of delipidated brain homogenate /I/. Attempa have been made to characterize these compounds.

Five fractions eluting in column working volume were obtainable by Sephadex G-25 chromatography of water soluble part of chloroform-methanol extract prepared from rat brain homogenate incubated under conditions optimal for aspartate deamination. Fractionation of the same preparation on DFAE-Sephadex resulted indetection fourteen peaks. In both cases a fraction was revealed in which increase of amide ammonia content as compared to control was accompanied by phosphorylation of compounds present in this one. Phosphorylation of such a fraction was confirmed in experiments with a ${ }^{32} \mathrm{P}$ - labelled ATP. It was ascertained that phosphorylating ammonia acceptor is the peptide with molecular weight of IIOO.

The data obtained permit us to asaert that ammonia forming in brain deamination procosses is bound in phosphate residues of phosphopeptides.

Kometiani, P.A., Klein, E.E., Gralia, N.V. and Gotsiridze, E.G. (I970): J. Neurochem. I7, I33I-I337. 